\title{
Extent of Implementation of ECE Programme by County Governments: The Case of Public Preschools in Eldoret West Sub- County, Kenya.
}

\author{
Selina J. Koskey, Hellen N. Inyega, Mulwa Peter K.
}

University of Nairobi

\section{ABSTRACT}

Kenya Constitution (2010) devolved the management of Early Childhood Development Education (ECE) to county govern- Selina J. Koskey ments. The 2014 County ECE Education Bill mandated the University of Nairobi Country Governments with several responsibilities of managing ECE services. These included ensuring: all schools have a functional feeding programme; safety of all children; more teachers are employed to reduce the teacher-pupil ratio; quality assurance services are provided promptly; teachers undertake professional development courses including those of handling learners with special needs; all preschools are registered; and teachers are appropriately remunerated. However, various challenges continue to undermine implementation of ECE programmes at county level. Emile Durkheim's Structural Functionalism Theory (18581971) informed the study and so points out that an institution should be structured in a way that various bodies are put in place How to cite this article:

Selina J. Koskey, Hellen N. Inyega, Mulwa Peter K.Extent of Imple mentation of ECE Programme by County Governments: The Case of Public Preschools in Eldoret West Sub-County, Kenya. American Jour so that each functions on behalf of the society. Findings indicate that Uasin Gishu County Government needs to put in more effort in order boost its current ECE provision services.

\section{Keywords:}

nal of Educational Research and Reviews, 2018,3:39.

County Governments; Pre Primary1, Pre Primary2, ProfessioneSciPub LLC, Houston, TX USA. al Development;; Teaching Resuorces; Teacher Remuneration. 


\section{Introduction}

Early Childhood Care and Education in Kenya is valued because it is a stage where children's future life is laid. This is a period where all aspects of one's development are determined. The early years are characterized by remarkable physical, emotional and cognitive development which is foundation for future learning and training UNESCO (2012). A firm foundation is always never shaken by any turbulence of life and therefore this puts an individual in a position where he or she is able to cope with any life situations. According to UNESCO (2014) education which is offered to the children should be that which embraces sustainable development and for this to be achieved; the provision of quality education and learning environment should be well managed and accorded priorities as this will propel a country's social and economic development.

Despite the growing importance of Early Childhood Development Education, there are a number of challenges that continue to pull down its effective implementation. It remains under developed globally due to lack of adequate and quality service in large proportions of ECE centres (Essa, 2010). According to International Task Force (2010) there is a shortage of professionally trained and qualified ECE teaching staff in many countries, majority of ECE teaching staff tends to be inferior to those of their counterparts in the education sector. These challenges have been met with success yet in other countries they remain a challenge as supported by UNESCO (2005) which notes that; organs of the United Nations such as UNESCO have advocated for the concept of decentralization to address the challenges facing the education sector. In some cases it is a question of increasing efficiency in management and administration in sectors concerned with ECE service provision.

In the United States, provision of ECE is decentralized to the states whose working standards are weak and working conditions of
ECE teaching staff characterized by low wages and limited benefits, their qualification requirements and salaries are comparatively lower, consequently leading to high turnover rates and difficulty in recruiting new teachers (International ECE Task Force 2010). Similarly, teachers in the United Kingdom and California were also considered leaving the profession; they ranked salary considerations as the most important factors driving their decision (Essa, 2010). When teachers are faced with such situation, they are normally de-motivated and hence do not perform their work to the expectation.

In Denmark both the ministry of social affairs and municipalities have the mandate of managing ECE programmes. Though around $65 \%$ of all teaching staff hold a bachelor's degree their salaries are on average lower than the salaries of primary school teachers (Cissokho, 2010). This like as argued by (Essa, 2010) still makes the implementation of ECE programmes a challenge since there is a mismatch between the teachers' salaries and their qualification hence poor motivation.

In Gambia for instance, ECE is provided by NGOs, local communities and largely provided by the private sector.A few training facilities are available for ECE teachers, this service is provided by some faith based organizations. Their salaries like that paid to ECE teachers in Denmark and USA is much lower (World Bank, 2012). This information does not explain levels of training given to the teacher hence an indication of lack of a clear policy in provision of ECE. The 2009-2015 policy states that the Gambian Government had the responsibility of allocating resources for successful implementation of the programme. However, funding received from the various partners was not enough to pay the teachers well and was also not well accounted for (World Bank,2012).

UNESCO (2010) in its comparative study of the issues surrounding success of ECE programmes in Nigeria, Lesotho, and Guinea Bissau noted that trained teachers are the 
major determinants of excellent performance of projects in a school setting. It continues to argue that the quality of a teacher depends on educational background and training (Essa,2010). The findings showed that, the Nigerian government made the greatest strides in the ECE teachers' quality improvement through the various trainings that were carried out in the ministry of education.

In Tanzania the responsibility of child rearing and ECE projects implementation in many places has remained in the hands of individual families and communities without proper and competent institutions to provide for their continued needs of education and development (UNICEF 2012).

In Uganda ECE is considered paramount in helping lay foundation of achieving quality education but teacher training is still one of the components that attract inadequate funding from the government (Ejuu 2012). The role of ensuring quality service provision in ECD is dependent on training of quality ECD teachers. In Uganda most ECD teacher training colleges are privately owned with the exception of Kyambogo University which is a government institution (Ejuu 2012). They therefore operate with little government control and regulation and hence a compromise of quality. Various private colleges have their own different curriculum for teaching and examining their students. Such variations lead to difference in quality of the certificates awarded by the colleges ( Ejuu, 2012).

According to Felicity and Anne (2011) most counties in Kenya in pre devolution showed that there was a problem of inadequate qualified ECE teachers; the number of untrained teachers in ECE was at $56 \%$ in the public ECE centres. Due to high rates of attrition many preschool managers had problems of recruiting untrained teachers who lacked skills to enhance the holistic development of children; this problem emerged as a result of the poor pay packages.(Gichuki, 2015). Devolution succeeds best when the various functions of the actors are clearly defined and delineated. The county governments who are mandated by the Kenyan constitution to manage ECE need to address the factors that would lead to optimal performance by the ECE teachers.

ROK (2014) Opined that the board of management constituted in school should ensure premises meet the requirements of the occupational health, safety regulations and building standards; ensure the welfare and safety of learners, teachers, non-teaching staff and other persons within the institution; thirdly, put in place firefighting equipment, first aid and other emergency equiprnent and nonprescription medicine. The size of the classrooms should not be less than $8 \mathrm{~m} \times 6 \mathrm{~m}$ and should hold not more than fifteen children Such kind of a learning environment will ensure quality since the classroom is spacious and allows learners' free movement and interaction in class. Additionally, the 1:15 ratio ensures teachers are able to attend to all children. Further, the teachers' pay should commensurate their qualification (Gichuki, 2015). (ROK 2014) also stressed the need for schools to be registered for easy management.

Owala etal,( 2016) points out that there are inadequate teaching and learning materials, teachers are poorly remunerated and therefore this places the provision of ECE services on a shaky ground. ECE teachers are de-motivated and their job performance has been compromised yet it is viewed important in the contemporary society. Well ventilated and painted classrooms, adequate play area, clean compound, availability of teaching and learning materials contribute to teachers' contentment with the working environment (Mosomi,2015). This shows that unmaintained physical working conditions, inadequate outdoor play equipment and lack of learning materials render an environment which impedes performance of both teachers and learners. Chepkong'a (2017) supports this and hence argues that the same problem hindered the provision of quality ECE services in west Pokot County and therefore 
recommended the county Government source funds for putting up enough and quality physical facilities in the ECE centres.

Little has been done by the government in the past to promote $E C E$, instead the decentralizing of the sector to non-government organizations and communities made it to be monopolized by the private sector, turning it into a private venture whose quality was questionable (Gichuki 2015). This made the provision of ECE to adopt various dimensions since supervision of the same services was not well managed. For instance, the Kenyan government did not aid in teacher preparation, construction of the much needed learning facilities; a number of pre-school did not have permanent buildings and teaching and learning was usually held outdoors under trees (Nganga 2009). Equally lack of professional development opportunities for teachers and high children to teacher ratios was a problem. In addition, teachers lacked adequate teaching and resources to enable them to implement ECE curriculum effectively this as supported by Okewa (2017) who also asserts that in Nyando Sub County of Kisumu County, the teachers are underpaid and schools also lack sufficient physical facilities.

Despite devolving the sector to county governments research has shown that there is a still concern of ineffectiveness in service delivery in various counties. For instance, Gichuki (2015) in his research reports that the Embu county government has low priorities for this sector of education as was indicated by low motivation exhibited by the teachers throughout Embu West Kenya. ECE teachers received compensation below the publicly pronounced minimum wage, teachers were therefore not committed to their job as they considered their appointment a temporary stop gap measure to give them time to look for better jobs elsewhere. In addition, some research findings in Kenya have revealed several factors that have continued undermine the implementation of ECE programmes. These include: poor remuneration, lack of or poor physical infrastructure, high pupil teacher ratios, lack of terms of service and lack of specialized teacher training (Owala,Odongo \& Raburu, 2016). However, in the face of these challenges ECE teachers have the potential to perform but they need to be motivated to have increased output in public ECE centres.

Devolution succeeds best when the various functions of the actors are clearly defined and delineated. The county governments who are mandated by the Kenyan constitution to manage ECE sector need to address the factors that would lead to optimal performance by the ECE teachers.

\section{Theoretical Framework}

The study is guided by Emile Durkheim's Structural Functionalism theory1858-1971.The theory proposes that a human society is like an organism and is made up structures called social institutions. These institutions are specially structured so that they perform different functions on behalf of the society, each of which has particular consequences for the form and shape of society. Durkheim believed that society is a complex system of interrelated and interdependent parts that work together. According to this study the county Government which has various partners in the provision of ECE need to provide good management so that these services are well implemented in order to help shape future citizens that Kenya needs.

\section{Methodology}

This study was based on descriptive research design. It targeted all the one hundred and eighty Public Primary schools with ECE Centres attached to them, Public Primary school head-teachers who are secretaries to the management board, all pre-primary school teachers and all ECE Zonal supervisors in the study area. Proportionate sampling technique was used to select 54 schools from the nine zones, and 54 ECE teachers to take part in the study. Purposive sampling technique was used to select the 9 ECE Zonal supervisors and 54 head-teach ers from the sampled schools. 
Questionnaire and interview guide were the research instruments used in the study.

Findings
After analysis, data was presented in tabular form using frequencies percentages and bar graphs as shown in tables 1 and 2 and also figure 1.

\section{Table 1: ECE Teachers Views on County Governments' Roles on ECE Programme Implementation}

\begin{tabular}{lccccc}
\hline & & YES & \multicolumn{2}{l}{ NO } \\
\cline { 2 - 6 } Statement & & Freq & \% & Freq & $\%$ \\
\hline Are you satisfied with your job? & 20 & 37 & 34 & 63 \\
Is your classroom spacious enough? & 43 & 80 & 11 & 20 \\
Do you have enough teaching and learning resources? & 11 & 20 & 43 & 80 \\
Are you employed on permanent basis? & 0 & 00 & 54 & 100 \\
Do have suitable furniture for your learners? & 14 & 30 & 38 & 70
\end{tabular}

Source: Field data

The findings (Table 1) shows that Eldoret west Sub County has succeeded in ensuring that $43(80 \%)$ of the ECE classrooms are spacious as this gives children comfort and a chance to freely interact with their peers. These findings therefore are in agreement with ROK (2014) which advocated for children's comfort as an aspect which enhance learning. It was also found out that $34(63 \%)$ of the teachers were not satisfied with their jobs $100 \%$ of them not on permanent employment, $43(80 \%)$ did not have enough teaching and learning resources and $38(70 \%)$ of them also did not have suitable furniture in their classrooms. This was noted by Mosomi (2015) and Owala etal (2016) who argued that poor working conditions and low pay de motivates teachers. ECE teachers in Eldoret West apart from enjoying the provision of spacious classrooms, they still need their morale be boosted in terms of good pay and being in classrooms that provide a chance for maximum teaching.
Information sought from head teachers with regard to the role of County government on implementation of ECE programme showed that; $42(78 \%)$ of the schools are registered and $38(70 \%)$ responded that the county Government had build classrooms in their schools. These responses showed an adherence to the requirements of ROK (2014) that county governments should register schools for easy access and construct classrooms for Pre Primary1 and Pre Primary2 learners. However, the county government never complied in ensuring that their newly recruited teachers do not quit their jobs after recruitment this because $33(61 \%)$ responded to have witnessed this happen. Another proportion of $44(81 \%)$ said that they did not get any teaching and learning resources and the same proportion also were in response that the ECE Zonal supervisors do not regularly supervise their teachers. These responses were not in support of ROK (2014) which opined that there 
was need to mind the quality of service clear indication that ECE in Eldoret West Sub provision in ECE centres this therefore gives a County stands on a shaky ground.

\section{Table 2: Head Teachers' Views on County Governments' Roles on ECE Programme implementation}

\begin{tabular}{|c|c|c|c|c|}
\hline & & YES & NO & \\
\hline Statement & & Freq \% & Freq & $\%$ \\
\hline Do your ECE teachers quit their job after recruitment? & 33 & 61 & 21 & 39 \\
\hline $\begin{array}{l}\text { Has the county government build an ECE classroom in you } \\
\text { school? }\end{array}$ & 38 & 70 & 16 & 30 \\
\hline $\begin{array}{l}\text { Do you get the teaching and learning resources from } \\
\text { the county government? }\end{array}$ & 10 & 19 & 44 & 81 \\
\hline $\begin{array}{l}\text { Do ECE Zonal supervisors regularly supervise their } \\
\text { teachers? }\end{array}$ & 10 & 19 & 44 & 81 \\
\hline Is your school registered? & 42 & 78 & 12 & 22 \\
\hline
\end{tabular}

Source: Field data

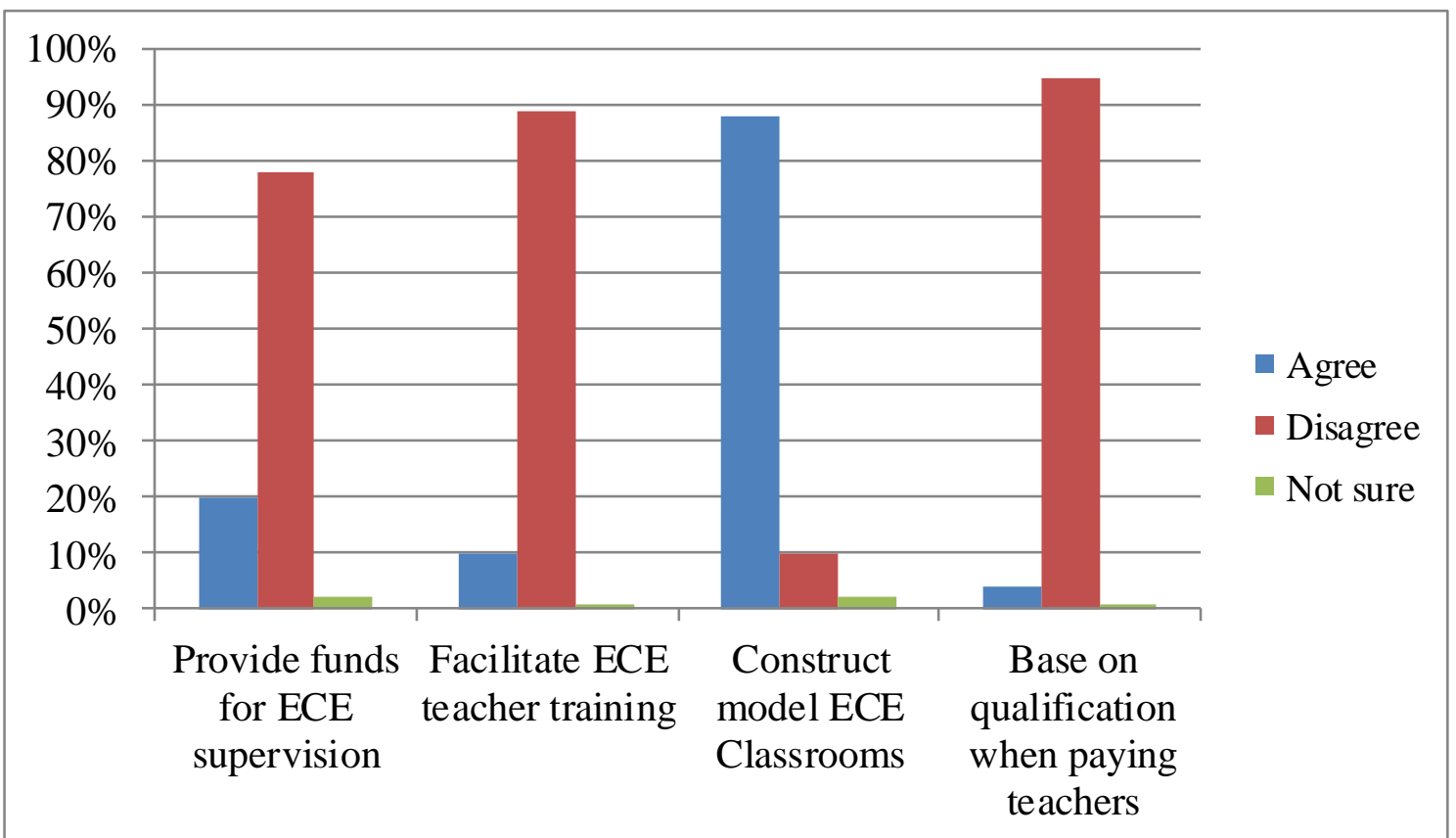

Figure 1: Zonal supervisors' views on County Government's roles and ECE management.

The zonal supervisors monitor the quality service provision in ECE centres. The findings indicate that lack of funding has made the Zonal Supervisors not to do their job since $78 \%$ of them responded that the county government never provides any financial support. This concurs with World Bank (2012) that ECE services do not get enough funding. It was evident at $88 \%$ response that the county government has helped in constructing model classrooms in Edoret West Sub County; $88 \%$ of the Zonal Supervisors gave this information which in this case supports ROK (2014) and its suggested strategy to boost ECE services. However $88 \%$ of the Supervisors said that the ECE teacher training is never facilitated. $98 \%$ of them also said that ECE teachers' pay did not commensurate their qualification. This 
response is in agreement with Ejuu,(2012) which reported that the government of Uganda did not adequately finance the ECE teacher training and therefore the ball was rolled to private colleges that never minded about quality. ROK (2014) also suggested that ECE teachers should be paid by the County Government basing on one's qualification; but to date this has never been implemented in Eldoret West Sub County. This scenario has made majority of the teachers view their current job as a stepping stone to another better job.

\section{Conclusions}

Good management of any institution or programme calls for total support in terms provision of both human, financial and physical resources. Most ECE centres in Eldoret West sub County have inadequate physical facilities like tables and chair though the classrooms are spacious, the sub county also does not provide funds to cater for teacher training and also supervision of practicing teachers. However it has made some progress in ensuring all the schools are registered

\section{Recommendations}

The county government needs to establish a public - private partnership framework to enhance financing and establishing of working conditions in ECE centres across the county. The county government needs to enhance a framework that maintains and rehabilitates physical infrastructure in ECE centres across the county to ensure that they are conducive and practical for the process of teaching. There is also need for the County Government to pay the ECE teachers basing on their qualification, and also strengthen ECE teacher training as this gives room for teacher development.

\section{References}

1. Chepkong'a, M.C., (2017).Influence of Learning Facilities on provision of Quality Early Childhood Development Centres in Kenya.International Journal Of Education and Reasearch. Vol 5(6) pp 15-26.
2. Cissokho, M. (2010). Value Orientation, Needs Satisfaction and Job Performance in Mauritius Phd Desertation. Calabar:University of Calabar.

3. Ejuu (2012).Implementing The Early Childhood Development teacher Training Framework in Uganda: Gains and Challenges :Journal of Early Childhood Research

4. Essa, D. (2010). Organizing for Effective Early Childhood Programmes. Cambridge: Havard University Press.

5. Felicity W. and Anne K. 2011). Early Childhood Development Education in Kenya: A literature Review on Current Issues. International Journal of Current ResearchVol 3, Issue 11 pg. 129-136

6. Gichuki Kamau J. (2015). Managerial Influence on Classroom Performance of Pre- School Children in Embu West, Embu County. Unpublished Mastersthesis University of Nairobi

7. Nafungo, J. (2015). Factors Influencing the Implementation of Quality Early Childhood Development Programme in Kenya's Informal Settlements; A Case of Kibera Slums In Nairobi County ,Kenya. Unpublished Mastersthesis University of Nairobi

8. Nganga (2009).Early childhood education programmes in Kenya: challenges and solutions, Early years; 29; 3, 227-236.

9. Owala Z.M,Odongo B. and Raburu P. (2016). Motivational Factors Influencing Teachers Job Performance in Pre-School centres in Kenya . International Journal of Innovative Research and Development, Vol 5( 5) pp 121-132

10. UNESCO (2005) Decentralization in Education: National Policies and Practices. Education policies and Strategies 7 Paris: UNESCO

11. UNESCO (2010) Education for All by 2015: will we make it? Paris :UNESCO

12. UNESCO (2012).EFA Global Monitoring Report 2012 - Youth and skills: Putting education to work. Paris: UNESCO.

13. UNESCO,(2014). EFA global monitoring report 2013/2014: Teaching and learning. Paris: UNESCO

14. Task Force (2012).Early childhood Education: Aglobal Scenario.Accessed from https:/download.ei.ei.org/docs/weddepot/ECEglobal-scenario-EN.PDF accessed 15/8/2018.

15. World Bank, (2012). In search for equal opportunities for all. Lima: Peru 